Green, M. \& Wilson, P. W. (1953). J. gen. Microbiol. 9, 89-96.

\title{
The Utilization of Nitrate Nitrogen by the Azotobacter
}

\author{
By MARGARET GREEN AND P. W. WILSON \\ Department of Bacteriology, University of Wisconsin, \\ Madison, Wisconsin, U.S.A.
}

SUMMARY: Four types of utilization of nitrate nitrogen were observed with fourteen strains of the azotobacter. These were:

(a) Those which utilize $\mathrm{NO}_{3}^{-}-\mathrm{N}$ with no or only a short lag; three strains of Azotobacter vinelandii, a stock culture of $A$. chroococcum C-77, and seven strains of A. chroococcum freshly isolated from soil were in this group;

(b) A single strain, a stock culture of $A$. chroococcum $\mathrm{C}-44$, which uses $\mathrm{NO}_{3}^{-}-\mathrm{N}$ only when conditions permit selection of a mutant capable of using this form of nitrogen;

(c) A single strain, $A$. indicum 10, which uses $\mathrm{NO}_{3}^{-}-\mathrm{N}$ very slowly in air and in which $\mathrm{NO}_{-}^{-}-\mathrm{N}$ accumulates ;

(d) A single strain, $A$. agile 4.4, which does not use $\mathrm{NO}_{3}^{-}-\mathrm{N}$. Certain other morphological and physiological differences between strains of $A$. vinelandii and the strain of $A$. agile 4.4 are pointed out which suggest that the question of the recognition of these strains as a single species be re-examined.

It has been generally accepted by workers in soil bacteriology that species of the azotobacter can grow equally well in nitrate, nitrite and ammonia and on molecular nitrogen. Robbins (1937), in a philosophical discussion dealing with the utilization of various types of nitrogen compounds by plants, stated that he knew of no reports on organisms that could use $\mathrm{N}_{2}$ but were unable to use ammonia or nitrates. Actually, at least one report suggesting that exceptions might occur does exist. In their monograph on the azotobacter Stapp \& Ruschmann (1924) noted that strains of Azotobacter chroococcum supplied with $\mathrm{NH}_{4} \mathrm{NO}_{3}$ used ammonia exclusively until it was exhausted, then slowly used the nitrate with accumulation of nitrite. The use of stagnant cultures in air, together with the low level of combined nitrogen (10-20 $\mu \mathrm{g} . / \mathrm{ml}$.), suggests that the original culture did not use nitrate, but that by growth on $\mathrm{NH}_{4}^{+}$and $\mathrm{N}_{2}$ a population was obtained from which nitrate-reducing mutants were selected.

While investigating the properties of mutants of $A$. agile selected by exposing cultures to ultraviolet light followed by penicillin screening (Lederberg, 1950), we found that the strains obtained had not only lost the ability to fix $\mathbf{N}_{2}$ but also were unable to grow on nitrate (or nitrite), although growth was normal on ammonia or casein hydrolysate. The significance of this observation in relation to the mechanism of nitrogen fixation was definitely lessened when it was found that the parent culture likewise did not use nitrate. This unexpected finding led to an examination of stock cultures of typical strains of the azotobacter for their ability to use nitrate in the presence and absence of other sources of nitrogen. The results described in this report 
demonstrate that previously held concepts regarding this important aspect of the physiology of these nitrogen-fixing organisms have been incomplete and even erroneous.

\section{METHODS}

Cultures. The following stock cultures in the University of Wisconsin collection were used: $A$. vinelandii 0 (Wisconsin stock), $A$. vinelandii 3 (from Dr R. L. Starkey in 1946), A. vinelandii B (from Dr Dean Burk, 1940), A. agile 4.4 (from Dr H. A. Barker, 1947), A. chroococcum C-44 (from Dr R. L. Starkey, 1948), A. chroococcum C-77 (Wisconsin stock), and A. indicum 10 (from Dr R. L. Starkey, 1946). In addition, seven strains of $A$. chroococcum (C-1 to C-7) were used immediately after isolation from soil in Wisconsin.

Media and conditions of growth. Stock cultures were maintained on Burk's or Ashby's agar containing $2 \%$ (w/v) sucrose (Wilson \& Knight, 1952); strains of $A$. chroococcum grew better on Ashby's agar.

Working cultures were grown in Erlenmeyer flasks in Burk's medium containing $2 \%(\mathrm{w} / \mathrm{v})$ sucrose and were incubated at $30^{\circ}$ on a rotary shaker (360 r.p.m.). To insure adequate aeration, the medium did not exceed one-fifth of the volume of the flask. All nitrogen sources, except nitrite which was sterilized by filtration, were autoclaved either separately or in the medium

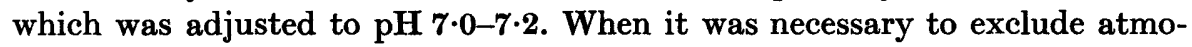
spheric nitrogen, the flasks were fitted with rubber stoppers and outlets to permit evacuation and replacement with hydrogen and oxygen. Adequate oxygen was supplied at intervals by evacuation and refilling.

Growth was determined turbidimetrically with an Evelyn colorimeter using a $660 \mathrm{~m} \mu$. filter (Wilson \& Knight, 1952). Velocity constants ( $k$ values) reported are averages of at least duplicate experiments consisting of two replicates each. The cultures were grown in standard Evelyn tubes containing $11 \mathrm{ml}$. of medium and were incubated at $30^{\circ}$ on a rotary shaker. When necessary, these tubes were fitted for hydrogen-oxygen atmospheres.

Chemical analyses. Total nitrogen was determined by the Kjeldahl method (Wilson \& Knight, 1952). Nitrate nitrogen in the supernatant culture medium was reduced to ammonia by Devarda's alloy, and the ammonia was determined by titration after aeration or steam distillation into boric acid. Nitrite nitrogen was determined with the sulphanilic acid and alphanaphthylamine reagents.

\section{RESULTS}

Velocity of growth on different sources of nitrogen. The velocity constants of growth for various species of the azotobacter when grown on $\mathrm{N}_{2}, \mathrm{NH}_{4}^{+}-\mathrm{N}$ and $\mathrm{NO}_{3}^{-}-\mathrm{N}$ are summarized in Table 1 . In these experiments, $0.3 \mathrm{mg} . / \mathrm{ml}$. $\left(\mathrm{NH}_{4}\right)_{2} \mathrm{HPO}_{4}-\mathrm{N}$ and $0.2 \mathrm{mg} . / \mathrm{ml}$. $\mathrm{KNO}_{3}-\mathrm{N}$ were used. With $\mathrm{NO}_{3}^{-}-\mathrm{N}$ an atmosphere of $40 \% \mathrm{O}_{2}$ in $\mathrm{H}_{2}$ was supplied to prevent growth on $\mathrm{N}_{2}$; this is an unnecessary precaution with the $\mathrm{NH}_{4}^{+}-\mathrm{N}$ since $0.3 \mathrm{mg} . / \mathrm{ml}$. completely inhibits fixation. A disadvantage of using the $\mathrm{H}_{2}+\mathrm{O}_{2}$ atmosphere is that $\mathrm{O}_{2}$ soon becomes the limiting factor for growth. For example, a $500 \mathrm{ml}$. Erlenmeyer flask containing $100 \mathrm{ml}$. of medium (containing $2 \mathrm{~g}$. sucrose and $30 \mathrm{mg}$. 
$\mathrm{NO}_{3}-\mathrm{N}$ ) would require at least $1.5 \mathrm{l}$. of $\mathrm{O}_{2}$ for complete oxidation of the sucrose and consequently complete utilization of the combined nitrogen. This would necessitate about twenty separate evacuations and refillings with $20 \% \mathrm{O}_{2}$ in $\mathrm{H}_{2}$ mixture. For this reason less medium was used with such cultures and the $\mathrm{pO}_{2}$ raised to $\mathbf{0 . 4} \mathrm{atm}$. All inocula for these experiments were grown in $\mathbf{N}_{2}$ for $24 \mathrm{hr}$. and were standardized so that the initial cell concentration was $10^{5} / \mathrm{ml}$.

Table 1. Growth of the azotobacter in molecular nitrogen, ammonium nitrogen and nitrate nitrogen

\begin{tabular}{|c|c|c|c|c|c|c|}
\hline \multirow[b]{2}{*}{ Strain } & \multicolumn{2}{|c|}{$\mathrm{N}$ fixed $(\mu \mathrm{g} . / \mathrm{ml})}$. & \multicolumn{3}{|c|}{$k$ value in } & \multirow{2}{*}{$\begin{array}{c}\mathrm{NO}_{3}^{-}-\mathbf{N} \\
\text { recovery } \\
\%\end{array}$} \\
\hline & $60 \mathrm{hr}$. & Maximum* & $\mathbf{N}_{2}$ & $\mathrm{NH}_{4}^{+}-\mathrm{N}$ & $\mathrm{NO}_{3}^{-}-\mathbf{N}$ & \\
\hline A. vinelandii 0 & 142 & $\mathbf{3 5 1}$ & $0 \cdot 34$ & 0.35 & $0 \cdot 36$ & $\mathbf{0}$ \\
\hline A. vinelandii 3 & 148 & $\mathbf{3 5 9}$ & $0 \cdot 36$ & $\mathbf{0 \cdot 3 6}$ & $0 \cdot 28$ & o \\
\hline A. agile 4.4 & 241 & 338 & $0 \cdot 38$ & $0 \cdot 40$ & 0 & 101 \\
\hline A. chroococcum C-44 & 172 & 345 & $0 \cdot 44$ & $0 \cdot 38$ & $0(0 \cdot 28)$ & $100(0)$ \\
\hline A. chroococcum C-77 & 115 & 237 & $0 \cdot 40$ & $0 \cdot 37$ & 0.44 & 0 \\
\hline A. chroococcum C-1 & 142 & 288 & $0 \cdot 40$ & $0 \cdot 36$ & $\mathbf{0 \cdot 3 5}$ & $\mathbf{0}$ \\
\hline A. indicum 10 & 16 & 351 & 0.07 & $0 \cdot 35$ & 0.32 & 36 \\
\hline
\end{tabular}

$k$, the velocity constant of growth, is equal to $2 \cdot 3$ times the slope of the linear portion of the curve obtained by plotting the log optical density $(O D)$ against time in hours (see Figs. 1 and 2).

* Determined when $2 \%$ sucrose was exhausted, usually 3-4 days except for $A$. indicum which required 7-10 days for maximum growth and when sucrose was often still present, and for $A$. chroococcum C-77 and C-1 strains which often did not exhaust the sucrose.

Some replicate cultures grow after a lag of 3 or more days.

Table 2. Growth of the azotobacter on casein hydrolysate and glutamate in an atmosphere of $\mathrm{O}_{2}$ in $\mathrm{H}_{2}$

\begin{tabular}{|c|c|c|c|}
\hline \multirow[b]{3}{*}{4 rimlam } & \multicolumn{3}{|c|}{ Source of nitrogen } \\
\hline & $\mathbf{N}_{\mathbf{2}}$ & Casein hydrolysate & Glutamate \\
\hline & & & \\
\hline$k$ value & $0 \cdot 33$ & $0 \cdot 28$ & $0 \cdot 14$ \\
\hline Lag (hr.) & 12 & $\mathbf{3 4}$ & 50 \\
\hline Optical density* & 0.495 & $0 \cdot 174$ & $0 \cdot 081$ \\
\hline Cell N $(\mu \mathrm{g} . / \mathrm{ml} .)^{*}$ & 227 & 74 & 51 \\
\hline Supernate N $(\mu \mathrm{g} . / \mathrm{ml} .)^{*}$ & 8 & 167 & 191 \\
\hline A. agile 4.4 & & & \\
\hline$k$ value & $0 \cdot 38$ & 0.29 & $0 \cdot 23$ \\
\hline Lag (hr.) & 7 & 20 & 40 \\
\hline Optical density* & $0 \cdot 699$ & 0.509 & $0 \cdot 161$ \\
\hline Cell N $(\mu \mathrm{g} . / \mathrm{ml}) *$. & $\mathbf{2 3 4}$ & 191 & 89 \\
\hline Supernate $\mathbf{N}(\mu \mathrm{g} . / \mathrm{ml} .)^{*}$ & 12 & 59 & 138 \\
\hline
\end{tabular}

* At $48 \mathrm{hr}$. for $\mathrm{N}_{2}$ and casein hydrolysate and $96 \mathrm{hr}$. for glutamate.

Previous studies in our own and other laboratories with $A$. vinelandii had suggested that organic sources of nitrogen such as amino-acids are inferior to the inorganic sources (Wilson, Hull \& Burris, 1943). Growth on casein hydrolysate $(c .0 .25 \mathrm{mg} . / \mathrm{ml}$.) and on glutamate (earlier work had shown this one of the better sources of the individual amino-acids) was compared with that on $\mathrm{N}_{2}$ for a typical strain ( $A$. vinelandii 0 ) using nitrate and one unable to use it (A. agile 4.4); the results are given in Table 2. 
Period of lag. For interpretation of the results summarized in Table 1 the period of lag is important as well as the $k$ value, which measures the velocity of growth during the logarithmic stage. Typical lags are illustrated in the curves of Figs. 1 and 2. Except for strains of $A$. chroococcum, all the cultures had shorter periods of lag and somewhat greater velocity constants in $\mathbf{N H}_{4}^{+}-\mathbf{N}$ than in $\mathbf{N}_{2}$. In contrast, $A$. chroococcum $\mathrm{C}-77$ and $\mathrm{C}-1$ had shorter lag periods in $\mathrm{NO}_{3}^{-}-\mathbf{N}$ than in $\mathbf{N}_{2}$. Although the period of lag in $\mathrm{NO}_{3}^{-}-\mathbf{N}$ for all the remaining strains varied somewhat in replicate determinations, it always
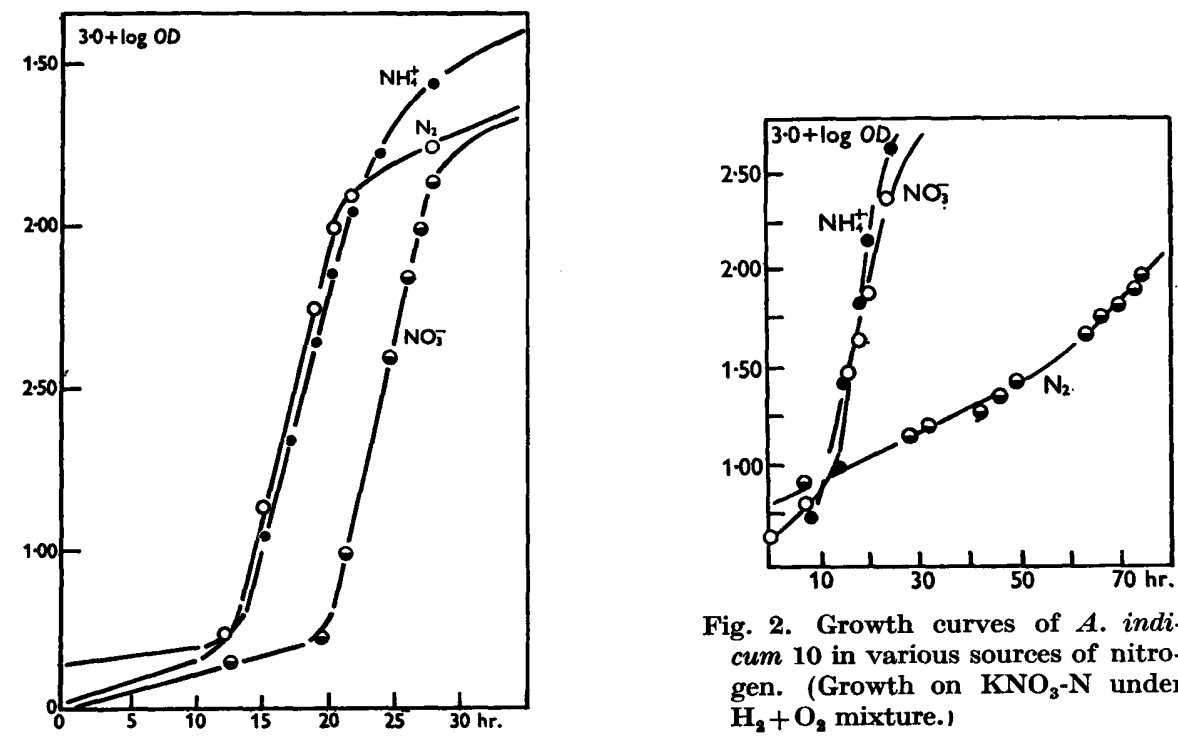

Fig. 2. Growth curves of $A$. indicum 10 in various sources of nitrogen. (Growth on $\mathrm{KNO}_{3}-\mathrm{N}$ under $\mathrm{H}_{\mathbf{2}}+\mathrm{O}_{\mathbf{2}}$ mixture.)

Fig. 1. Growth curves of A. vinelandii 0 on various sources of nitrogen. (Growth on $\mathrm{KNO}_{3}-\mathrm{N}$ under $\mathrm{H}_{2}+\mathrm{O}_{2}$ mixture.)

exceeded that of the cultures on ammonium or molecular nitrogen. The sole exception is $A$. indicum for which the results are not directly comparable with the others. First, this culture fixes $\mathbf{N}_{2}$ extremely slowly when the initial pH is 7.0 or above, especially if small inocula are used. Secondly, below an initial $\mathrm{pH}$ of $\mathbf{7 \cdot 0}$, although the lag period is shorter and the velocity constant of growth is higher, the heavy production of gum and the effect of $\mathrm{pH}$ on its production make determination of $k$ values based on turbidimetric readings highly questionable.

Adaptation to nitrate. The long lag of some of the cultures in nitrate-N, together with the occasional use of nitrate-N by $A$. chroococcum $\mathrm{C}-44$, could be accounted for either by the formation of adaptive enzymes or the selection of a mutant utilizing nitrate. The occurrence of both might be favoured by growing the cultures in the presence of nitrate, together with other forms of nitrogen. The initial trials were made with strains growing in $0.166 \mathrm{mg} . / \mathrm{ml}$. $\mathrm{NH}_{4} \mathrm{NO}_{3}-\mathrm{N}$ in air. All cultures grew well under these conditions except 
$A$. chroococcum C-44 and $A$. agile $4 \cdot 4$. The $\mathrm{pH}$ in these two cultures fell to about 5.0 because of the utilization of the basic ammonium ion. Under these conditions $\mathrm{N}_{2}$ cannot be fixed, and growth was stopped without detectable use of the nitrate. The results with $\boldsymbol{A}$. indicum deserve special mention. After 6 days no nitrate had been used, and the $\mathrm{pH}$ had dropped to $3 \cdot 2$. This unusual species of the azotobacter can survive even this low pH (Starkey, 1939), so that in 8 weeks it had metabolized about two-thirds of the nitrate, and the pH had correspondingly returned toward neutrality. These three cultures were accordingly retested, using only $0.7 \mathrm{mg} . / \mathrm{ml}$. $\mathrm{NH}_{4} \mathrm{NO}_{3}-\mathrm{N}$ with the results summarized in Table 3 . Under these conditions, only $A$. agile $4 \cdot 4$ did not use $\mathrm{NO}_{3}^{-}-\mathrm{N}$ in 4 days.

Table 3. Utilization of nitrate- $\mathrm{N}$ from small concentrations of $\mathrm{NH}_{4} \mathrm{NO}_{3}$ in air

\begin{tabular}{|c|c|c|c|c|c|}
\hline Strain & $\begin{array}{c}\text { Age } \\
\text { (days) }\end{array}$ & $\begin{array}{c}\text { Final } \\
\text { pH }\end{array}$ & $\begin{array}{l}\text { Optical } \\
\text { density }\end{array}$ & $\begin{array}{c}\text { Initial } \\
\mathrm{NO}_{3}^{-}-\mathrm{N} \\
(\mu \mathrm{g} . / \mathrm{ml} .)\end{array}$ & $\begin{array}{c}\mathrm{NO}_{3}^{-}-\mathrm{N} \\
\text { recovery } \\
(\%)\end{array}$ \\
\hline A. agile 4.4 & 4 & 6.5 & $0 \cdot 921$ & 35 & 104 \\
\hline A. chroococcum C-44 & $\begin{array}{l}1 \\
2 \\
4\end{array}$ & $\begin{array}{l}6 \cdot 1 \\
6 \cdot 3 \\
6 \cdot 4\end{array}$ & $\begin{array}{l}0 \cdot 215 \\
0 \cdot 367 \\
1 \cdot 046\end{array}$ & $\begin{array}{l}\mathbf{3 5} \\
\mathbf{3 5} \\
\mathbf{3 5}\end{array}$ & $\begin{array}{r}104 \\
64 \\
0\end{array}$ \\
\hline A. indicum 10 & $\begin{array}{l}1 \\
4\end{array}$ & $\begin{array}{l}6 \cdot 2 \\
4 \cdot 0\end{array}$ & $\begin{array}{l}0 \cdot 553 \\
1 \cdot 398\end{array}$ & $\begin{array}{l}35 \\
\mathbf{3 5}\end{array}$ & $\begin{array}{r}25 \\
0\end{array}$ \\
\hline
\end{tabular}

Another successful method for obtaining strains of $A$. chroococcum C-44 capable of using nitrate- $\mathrm{N}$ was by serial transfers using $1 / 10 \mathrm{vol}$. of the previous culture as inoculum in air in a medium containing $\mathrm{KNO}_{3}-\mathrm{N}$ (see Table 4). A. agile 4.4 did not use $\mathrm{NO}_{3}^{-}-\mathrm{N}$; the behaviour of $A$. indicum 10 under these conditions will be discussed in the next section on the formation of nitrite.

To determine if the utilization of nitrate- $\mathbf{N}$ resulted from a prolonged enzymic adaptation to nitrate similar to that taking place within a few hours

Table 4. Serial transfers of strains of azotobacter on $\mathrm{KNO}_{3}-\mathrm{N}$ in air

\begin{tabular}{|c|c|c|c|c|c|c|c|}
\hline Strain & $\begin{array}{c}\text { Transfer } \\
\text { no. }\end{array}$ & $\begin{array}{c}\text { Age } \\
\text { (days) }\end{array}$ & $\begin{array}{c}\text { Final } \\
\text { pH }\end{array}$ & $\begin{array}{l}\text { Optical } \\
\text { density }\end{array}$ & $\begin{array}{c}\mathrm{NO}_{2}^{-}-\mathrm{N} \\
(\mu \mathrm{g} . / \mathrm{ml} .)\end{array}$ & $\begin{array}{c}\text { Initial } \\
\mathrm{NO}_{3}^{-}-\mathrm{N} \\
(\mu \mathrm{g} . / \mathrm{ml} .)\end{array}$ & $\begin{array}{c}\mathrm{NO}_{3}^{-}-\mathrm{N} \\
\text { recovery } \\
(\%)\end{array}$ \\
\hline A. chroococcum & 2 & 2 & $7 \cdot 5$ & $1 \cdot 301 *$ & o & 319 & 102 \\
\hline \multirow[t]{3}{*}{ C-44 } & 5 & 7 & $7 \cdot 7$ & $1.523 *$ & o & 229 & 104 \\
\hline & 6 & 7 & $7 \cdot 7$ & $1 \cdot 699^{*}$ & $\mathbf{0}$ & 229 & 86 \\
\hline & 7 & 3 & $8 \cdot 2$ & 2.000* & 0 & 229 & 1 \\
\hline A. agile $4 \cdot 4$ & 7 & 7 & $7 \cdot 6$ & 1.000 & $\mathbf{0}$ & 166 & 100 \\
\hline \multirow[t]{2}{*}{ A. indicum 10} & $\mathbf{3}$ & 5 & $6 \cdot 8$ & $0 \cdot 180$ & 50 & 229 & $78 \dagger$ \\
\hline & 7 & 3 & $7 \cdot 0$ & $0 \cdot 215$ & 52 & 225 & $75 \dagger$ \\
\hline
\end{tabular}

* Black pigment present.

$\dagger$ Corrected for $\mathrm{NO}_{\overline{2}}^{-}-\mathrm{N}$ present; note that the recovery of $\mathrm{NO}_{3}^{-}-\mathrm{N}$ plus $\mathrm{NO}_{2}^{-}-\mathrm{N}$ is about 100 per cent and therefore $\mathrm{N}_{2}$ was serving as the source of nitrogen.

When $A$. chroococcum $\mathrm{C}-44$, (transfer no. 6 above) was inoculated into $0.3 \mathrm{mg} . / \mathrm{ml}$. $\mathrm{KNO}_{3}-\mathrm{N}$ in a $\mathrm{H}_{2}+\mathrm{O}_{2}$ atmosphere, all the nitrate-N disappeared in 4 days. $A$. indicum (transfer no. 7 ) used only $27 \%$ of the nitrate- $\mathrm{N}$ in 17 days under $\mathrm{H}_{2}+\mathrm{O}_{2}$ and $0 \cdot 053 \mathrm{mg} . / \mathrm{ml}$. $\mathrm{NO}_{\mathrm{a}}^{-} \mathrm{N}$ were present. $A$. agile (transfer no. 7 ) failed to grow in nitrate- $\mathrm{N}$ when $\mathrm{N}_{2}$ was excluded. Also continuous cultivation of $A$. agile through seventy-eight transfers in $0 \cdot 15 \mathrm{mg} . / \mathrm{ml} . \mathrm{NH}_{4} \mathrm{NO}_{3}-\mathrm{N}$ in air did not result in utilization of nitrate-N. 
with $A$. vinelandii 0 (Burris \& Wilson, 1946), Burk's medium containing $0 \cdot 166 \mathrm{mg} . / \mathrm{ml}$. $\mathrm{KNO}_{3}-\mathrm{N}$ was inoculated with all the strains of the azotobacter and incubated under $40 \% \mathrm{O}_{2}$ in $\mathrm{H}_{2}$. If small inocula were used $\left(10^{3}\right.$ cells $/ \mathrm{ml}$.), $A$. agile $4 \cdot 4$ and $A$. chroococcum $\mathrm{C}-44$ (occasional exceptions) failed to grow. $A$. chroococcum C-44, but not $A$. agile 4.4, grew when the size of the inoculum was increased to $10^{7}$ cells $/ \mathrm{ml}$. All other strains, except $A$. indicum, used up to $0.02 \mathrm{mg} . / \mathrm{ml}$. $\mathrm{KNO}_{3}-\mathrm{N}$ within 4 days with either large or small inocula when kept in the $\mathrm{H}_{2}+\mathrm{O}_{2}$ atmosphere. $A$. indicum used $\mathrm{NO}_{3}^{-}-\mathrm{N}$ but at a much slower rate.

Formation of nitrite. Although $\boldsymbol{A}$. indicum is capable of using nitrate, under certain conditions, the utilization is incomplete in a medium containing approximately $0.15 \mathrm{mg}$. $/ \mathrm{ml}$. total-N. Decreasing the initial $\mathrm{pH}$ of the medium did not alter this result in contrast to its effect on the fixation of $\mathrm{N}_{2}$. This incomplete utilization evidently arises from accumulation of toxic quantities of nitrite in the medium. For example, with $0.15 \mathrm{mg} . / \mathrm{ml} . \mathrm{NO}_{3}^{-}-\mathrm{N}$ initially present, as much as $0.05-0.06 \mathrm{mg} . / \mathrm{ml}$. $\mathrm{NO}_{2}^{-}-\mathrm{N}$ accumulated (its toxicity may be accentuated by the low $\mathrm{pH}$ frequently observed in cultures of A. indicum 10). Variation of the $\mathrm{pO}_{2}(0 \cdot 0-0.5 \mathrm{~atm}$.) or replacement of the hydrogen + oxygen atmosphere with one of helium + oxygen did not influence the accumulation. Serial transfers in nitrate-N did not select a culture which could use nitrite- $\mathbf{N}$ more readily.

Only occasionally with the other strains did nitrite accumulate: it did so with $A$. vinelandii 0 during the first few hours of growth on $0.35 \mathrm{mg} . / \mathrm{ml}$. $\mathrm{NH}_{4} \mathrm{NO}_{3}-\mathrm{N}$ in air, and with this culture and $A$. chroococcum $\mathrm{C}-44$ when oxygen was limiting $\left(\mathrm{H}_{2}+\mathrm{O}_{2}\right.$ atmosphere $)$.

\section{DISCUSSION}

All the stock strains of $A$. vinelandii tested grew readily on nitrate-N, but neither the parent nor a derived strain (the mutant unable to use $\mathrm{N}_{2}$ ) of $A$. agile $4 \cdot 4$ would use this source of nitrogen. Unsuccessful efforts to secure utilization of nitrate by this culture in addition to those summarized in the results included: $(a)$ a tenfold increase in content of molybdenum in the medium-this element is believed to be important in nitrate reduction (Steinberg, 1939)-and (b) reduction of the $\mathrm{pO}_{2}$. The classical method of genetics, the use of mutagenic agents, was not attempted. The inability to use nitrate- $\mathrm{N}$ by this culture does not arise from a lack of nitrate reductase alone since the culture likewise cannot use nitrite- $\mathrm{N}$ even when present in a non-toxic concentration of $0.02 \mathrm{mg} . \mathrm{N} / \mathrm{ml}$.

One culture (C-44) of the nine tested strains of $A$. chroococcum did not use nitrate- $\mathrm{N}$, but strains able to use nitrate were readily obtained from this culture, probably by selection of mutants. Another culture, A. indicum 10, used nitrate-N slowly in air and nitrite-N accumulated. Since all of the cultures grew well on $0.35 \mathrm{mg}$. $\mathrm{NO}_{3}-\mathrm{N} / \mathrm{ml}$. in air, regardless of whether this source of nitrogen or $\mathrm{N}_{2}$ was used, it is easily understood why inability to use nitrate- $\mathbf{N}$ by certain strains of the azotobacter was so long overlooked.

Finally, as previously reported, species of azotobacter grow more readily 
on $\mathrm{N}_{2}$ and $\mathrm{NH}_{4}{ }^{+}-\mathrm{N}$ than on organic nitrogen as evidenced by shorter periods of lag and greater $k$ values. Nevertheless, the growth on a complex mixture of amino-acids such as casein hydrolysate is considerably better than we had previously reported (Wilson et al. 1943); this is particularly true of $A$. agile 4.4.

Although probably none of these results could be generalized when so few strains have been used, the observed difference in the behaviour of the single strain of $A$. agile 4.4 and the three strains of $A$. vinelandii emphasizes the discrepancies that have resulted in a disparity of opinion regarding the validity of classifying $A$. vinelandii as a strain of $A$. agile (Hofer, 1948). Some differences which we and others (Winogradsky, 1938; Kluyver \& van Reenan, 1933) have observed between $A$. vinelandii and $A$. agile are:

(1) Morphologically, $A$. agile 4.4 is a much larger organism than any of our strains of $A$. vinelandii. A. agile 4.4 is particularly characterized by prominent intracellular particles (Eisenstark, Ward \& Kyle, 1950), some of which stain with dyes considered to be specific for mitochrondria. Capsular material and gum are much more evident in $\boldsymbol{A}$. agile, and the cell is much more resistant to breakage and does not autolyse readily in old cultures.

(2) Physiologically, $A$. agile $4 \cdot 4$ has a much shorter lag than has $A$. vinelandii when grown on $\mathrm{N}_{2}$ or $\mathrm{NH}_{4}^{+}-\mathrm{N}$, although the total quantity of $\mathrm{N}_{2}$ fixed and the efficiency of fixation do not differ markedly among the cultures. In addition to being unable to use nitrate-N, this strain of $A$. agile does not oxidize mannitol; $A$. vinelandii will use this source of carbon although the enzyme system is apparently adaptive.

Whether these differences are sufficient for recognition of two species could be debated and certainly their significance is dependent upon a wider survey of representative types.

It may also be mentioned that two characteristics of the azotobacter given by Hofer (1948) are not met by any of the cultures in our collection. The statement that members of the family grow best on media deficient in nitrogen has not been borne out by any modern physiological studies in which ammonia and urea have been used. The apparently contradictory statement that $\boldsymbol{A}$. chroococcum as a species is stimulated by non-toxic concentrations of nitrate probably is based on early experiments in which the physiology of nitrogen fixation, specifically the role of molybdenum, was not understood. Finally, the frequently used characteristic of pigmentation for differentiation of species is open to question since the presence of many of the pigments depends in a large part on the physiological environment, notably levels of iron, molybdenum and aeration (Wilson \& Knight, 1952). Because of these difficulties and the almost total lack of information based on modern physiological techniques, except for a very few strains, we prefer for historical reasons (Winogradsky, 1938; Kluyver \& van Reenan, 1933), as well as those discussed in this section, to maintain the two species, $A$. agile and $A$. vinelandii, until more compelling arguments are given for their merging. At present it is evident that this field once more needs a thoroughgoing survey analogous to that made 30 years ago by Stapp \& Ruschmann (1924). 


\section{REFERENCES}

Burris, R. H. \& Wilson, P. W. (1946). Ammonia as an intermediate in nitrogen fixation by Azotobacter. J. Bact. 52, 505.

Eisenstark, A., Ward, Jn. C. B., \& Kyle, T. S. (1950). A study of large bodies in Azotobacter agile. J. Bact. 60, 525.

Hofer, A. W. in Bergey's Manual of Determinative Bacteriology (1948). 6th ed. Edited by Breed, R. S., Murray, E. G. D. \& Hitchens, A. P. Baltimore, Maryland: Williams and Wilkins Co. p. 220.

KuUYver, A. H. \& ReEnen, W. J. van (1933). Utber Azotobacter agilis Beijerinck. Arch. Mikrobiol. 4, 280.

LEDERBERG, J. (1950). Isolation and characterization of biochemical mutants of bacteria. Meth. med. Res. 3, 5.

Robins, W. J. (1937). The assimilation by plants of various forms of nitrogen. Amer. J. Bot. 24, 243.

Stapp, C. \& Ruschmann, G. (1924). Zur Biologie von Azotobacter. Arb. biol. Abt. (Anst.-Reichsanst.), Berl. 13, 305.

STARKEY, R. L. (1939). The influence of reaction upon the development of an acidtolerant Azotobacter. Trans. Third Comm. Soc. int. Soil Sci. A, p. 142.

Steinberg, R. A. (1939). Effects of nitrogen compounds and trace elements on growth of Aspergillus niger. J. agric. Res. 59, 731.

Wilson, P. W., Hull, J. F. \& Burris, R. H. (1943). Competition between free and combined nitrogen in nutrition of Azotobacter. Proc. Nat. Acad. Sci., Wash. 29, 289.

Wilson, P. W., \& KNight, S. G. (1952). Experiments in Bacterial Physiology. Minneapolis, Minnesota: Burgess Publishing Co.

WinogradsKy, S. (1938). Etudes sur la microbiologie du sol et des eaux. Sur la morphologie et l'œecologie des Azotobacter. Ann. Inst. Pasteur, 60, 351.

(Received 7 February 1953) 